\title{
Sero-Prevalence of Antenatal Rubella in UITH
}

\author{
O.O. Agbede ${ }^{1}$, O.O. Adeyemi ${ }^{*}, 1$, A.W.O. Olatinwo ${ }^{2}$, T.J. Salisu ${ }^{3}$ and O.M. Kolawole ${ }^{4}$ \\ ${ }^{I}$ Department of Medical Microbiology and Parasitology, University of Ilorin, P.M.B. 1515, Ilorin, Nigeria \\ ${ }^{2}$ Department of Obstetrics and Gynecology, University of Ilorin, P.M.B. 1515, Ilorin, Nigeria \\ ${ }^{3}$ Department of Chemical Pathology, University of Ilorin Teaching Hospital, Nigeria \\ ${ }^{4}$ Department of Microbiology, University of Ilorin, P.M.B. 1515, Ilorin, Nigeria
}

\begin{abstract}
Rubella virus is a teratogen that may induce foetal death or Congenital Rubella Syndrome in the newborn. Studies carried out in Nigeria, have recorded $68.5 \%$ prevalence in pregnant women in the south-west and $54.1 \%$ in the North-west. There has been a dearth of information in the North central. Sentinel studies have placed the incidence of rubella on a seasonal distribution, with an average of 5-9-year variable epidemic pattern.

A descriptive study was carried out on pregnant women between July and September 2009, to establish baseline data on the sero-prevalence of antenatal rubella in pregnant women in Ilorin. A total of 92 pregnant women in the first and second trimesters of pregnancy were recruited from the antenatal clinics of the University of Ilorin Teaching Hospital.

A $3 \mathrm{ml}$ blood sample was collected from each consenting subject and serum assayed for Rubella IgG/ IgM antibodies by indirect ELISA test. Anti-rubella virus antibodies were reported in the sera of 14 pregnant women that participated in the study. A prevalence of $16.3 \%$ was recorded. The primigravidae had a higher prevalence $(27.0 \%)$ than the multigravidae $(12.0 \%)$. There was a gradual rise in seroprevalence from first trimester pregnancies $(13.0 \%)$ to second trimester pregnancies $(19.1 \%)$.

High seroprevalence of rubella infections during organogenesis poses high risk to foetus. Since $85 \%$ of the subjects were susceptible to rubella virus infection, it is advisable for health planners to prevent further occurrence of antenatal rubella that may result to congenital rubella anomalies by the immunisation of women of child bearing age.
\end{abstract}

Keywords: Sero-prevalence, antenatal rubella.

\section{INTRODUCTION}

Rubella is caused by a positive sense RNA virus of the family Rubiviridae. It affects all ages and sex [1]. Rubella virus is a biological teratogen of the TORCH complex [2]. Acute infections that occur in early pregnancy may induce foetal death or Congenital Rubella Syndrome [3]. Clinical manifestations of rubella include acute febrile illness, maculopapula rash and lymphadenopathy in adults and children [4]. These symptoms are often confused with similar rashassociated illnesses caused by other viral and non-viral pathogens or even some drugs, making differential diagnosis unreliable [1,5]. Rubella invokes a serological response that is detectable at the onset of its characteristic rash and continues to evolve over the next few weeks [1]. Viral-specific IgM antibodies are first detected 10 days post infection, and peaks at about 4 weeks post infection. This may persist for over 7 months after an acute infection. By three weeks post infection, anti-rubella virus antibodies are present in all immunoglobulin classes, including $\operatorname{IgG}, \operatorname{IgA}, \operatorname{IgD}$, and $\operatorname{IgE}$ [1]. The infectious period of rubella virus is from 7 days

*Address correspondence to this author at the Department of Medical Microbiology and Parasitology, University of Ilorin. P.M.B. 1515, Ilorin, Nigeria; Tel: +234 (0)8023333 740; E-mail: peluwa@yahoo.com before to 5-7 days after onset of rash [6]. At this period, the virus remains detectable only in the Nasopharynx, where it can be isolated from up to 1 week before, to up to 2 weeks after the onset of rash [4].

In early laboratory diagnosis of rubella infections, detection of plasma cells in circulating blood was considered as one of the diagnostic standards. However, further HAI studies have shown that plasma cell detection in rubella patients have a very low sensitivity and low specificity alike [7]. Viral isolation may occasionally be warranted particularly during infections in pregnancy, but this is expensive [1] and as a result of the non-cytopathic effect of rubella virus in cell cultures, it is not usually recommended [4]. Nucleic acid amplification techniques have been developed since the 1990s for the detection of rubella virus RNA in clinical samples of orophangeal sources [4]. However, a definitive diagnosis of rubella is a suspected case with a positive test for rubella-specific IgM in all ages, by ELISA $[1,4,8]$. Test results for the detection of rubella virus-specific IgG and IgM antibodies by ELISA are presented as positive, borderline and negative, which is a reflection of the spectra of the photocell detected light of the Spectrophotometry, which determines both qualitative and quantitative results in a given run. 


\section{Vaccination}

In 1969, a monovalent (inactivated) vaccine and a trivalent vaccine (i.e. Measles, Mumps and Rubella - MMR) were developed $[6,8]$, and have since been accepted worldwide and introduced into the WHO EPI [9] with a primary purpose of vaccination in women to prevent the occurrence of CRS [5, 10]. Although the burden of CRS is not well characterized in most countries $[4,11]$, it is estimated that over 100,000 infants are born with CRS each year, mostly occurring in developing countries that are yet to introduce rubella vaccines $[3,11]$.

In 1979, the Federal Government of Nigeria initiated the EPI which was sustainably re-vitalized in 1999 to reduce disease burden from vaccine preventable diseases but left out rubella [4]. Studies carried out in Nigeria, have revealed an annual occurrence of 150-250 new cases of congenital eye defect in the Federal Capital Territory [12]. In south western Nigeria, a $68.5 \%$ prevalence of rubella infection in pregnant women have been observed in Ibadan [13], and 76\% in Lagos [14]. In Maiduguri (North-western Nigeria) 54.1\% prevalence was however observed in pregnant women [15]. With epidemics occurring in varied intervals by geographical locations [3,6], sentinel studies have placed the incidence of rubella on a seasonal distribution, with an average of 5-9year epidemic pattern that is highly variable in both developed and developing countries [11].

\section{Study Objectives}

This study was carried out to establish baseline data on the sero-prevalence of antenatal rubella in pregnant women in Ilorin.

\section{MATERIAL AND METHODS}

A descriptive study was carried out at the Antenatal clinics of the University of Ilorin Teaching Hospital (UITH),
Ilorin. A total of 92 subjects were recruited by simple random selection from a population size of 124 pregnant women not exceeding 24 weeks of gestation, between July and September 2009. The sample size was determined by the Fisher's formula (for populations less than 10,000). Ethical approval was obtained from the Ethical Committee of UITH, before the study was carried out. A written informed consent was duly signed by each participating pregnant woman within the first and second trimesters of pregnancy. Pregnant women in the third trimester of pregnancy including other pregnant women who were not registered at, nor attended the antenatal clinics of the UITH, were excluded from this study.

\section{Sample Collection and Processing}

A structured questionnaire was designed and standardised. Data was collected by three trained research assistants through structured interviews. A $3 \mathrm{ml}$ blood sample was collected from each respondent into sterile non-anticoagulant bottles. Sera were separated by centrifugation at 3,000 rpm for 5 minutes and stored in serum vial aliquots at $-20^{\circ} \mathrm{C}$.

\section{Laboratory Analysis}

Sera were tested for Rubella virus-specific IgG and IgM antibodies by the enzyme-linked immunosorbent assay (ELISA) test; using the SERION ELISA classic Rubella Virus IgG/IgM kit (Germany) according to the manufacturer's instructions. All specimens were analysed by indirect ELISA techniques. IgG test results were interpreted as a ratio of the sample optical density (OD) of $450 \mathrm{~nm}$ and the sample rate/cut-off value as follows: $<0.30 \mathrm{U} / \mathrm{ml}=$ negative; 0.30 $0.55=$ Borderline; and $>0.55=$ positive. IgM test results were interpreted as similarly as follows: $<0.135 \mathrm{U} / \mathrm{ml}=$ negative; $0.135-0.230=$ Borderline; and $>0.230=$ positive . The controls and the calibrators passed the validation check recommended by the manufacturers of both the $\mathrm{IgG}$ and the IgM kits.

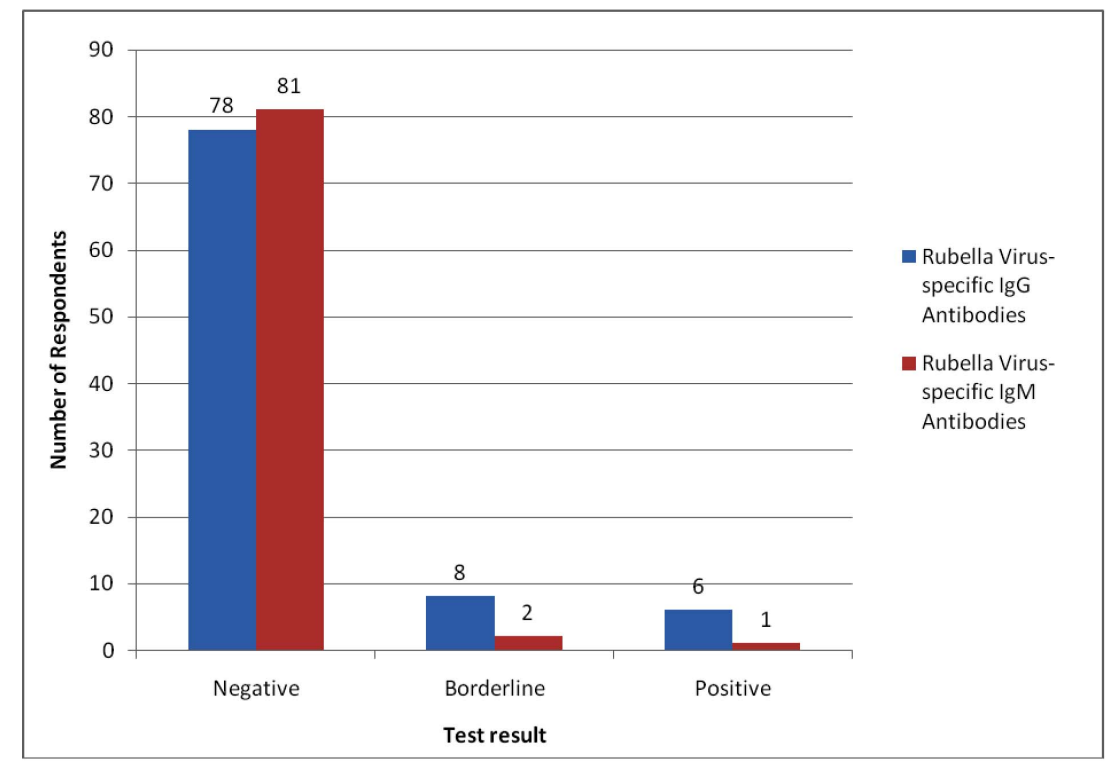

Fig. (1). Distribution of Rubella virus-specific IgG and IgM in the sera of pregnant women $(\mathrm{N}=92)$.

This figure shows the Distribution of Rubella Virus-specific IgG and IgM in the sera of the pregnant women that participated in this study. The IgG test results shows that $8(9.0 \%)$ pregnant women tested borderline, $6(7 \%)$ tested positive, while $78(85.0 \%)$ tested negative. Also, 2 (2.2\%) pregnant women's sera tested borderline for IgM, $1(1.1 \%)$ tested positive while $89(96.7 \%)$ of tested negative. 
Table 1. Prevalence of Rubella Virus Infection among Types of Pregnancy (N=92)

\begin{tabular}{|c|c|c|c|c|c|c|}
\hline Type of Pregnancy & No. Tested & \multicolumn{2}{|c|}{ New Cases: IgM +ve (\%) } & \multicolumn{2}{|c|}{ Old Cases: IgG +ve (\%) } & Prevalence of Rubella Virus Infection \\
\hline No response & 5 & \multicolumn{2}{|c|}{$1(20.0)$} & \multicolumn{2}{|c|}{$0(0.0)$} & $20.0 \%$ \\
\hline Primigravid & 37 & \multicolumn{2}{|c|}{$1(2.7)$} & \multicolumn{2}{|c|}{$9(24.3)$} & $27.0 \%$ \\
\hline Multigravid & 50 & \multicolumn{2}{|c|}{$1(2.0)$} & \multicolumn{2}{|c|}{$5(10.0 \%)$} & $12.0 \%$ \\
\hline Total & 92 & \multicolumn{2}{|c|}{$3(3.3 \%)$} & \multicolumn{2}{|c|}{$14(15.2)$} & $18.5 \%$ \\
\hline \multicolumn{2}{|c|}{ Statistical Test $(95 \% \mathrm{CI})$} & Lower: -0.056 & Upper: 0.009 & Lower: 0.019 & Upper: 0.187 & \\
\hline \multicolumn{2}{|c|}{ Statistical Test $(99 \% \mathrm{CI})$} & Lower: -0.067 & Upper: 0.020 & Lower: -0.008 & Upper: 0.214 & \\
\hline
\end{tabular}

This table shows the point prevalence of rubella infection among the types of pregnancy. It was observed that the prevalence of rubella virus infection among the primigravid pregnant women was $27 \%$ while it was $12 \%$ among the multigravid pregnant women. Statistical testing at $95 \%$ CI shows no significant difference however; at $99 \%$ CI there is significance.

Table 2. Prevalence of Rubella Virus Infection among Pregnancy Trimester $(\mathrm{N}=92)$

\begin{tabular}{|c|c|c|c|c|}
\hline Trimester & Total No. Tested & New Cases: IgM +ve (\%) & Old Cases: IgG +ve (\%) & Prevalence of Rubella Virus Infection \\
\hline \hline Not specified & 1 & $0(0)$ & $0(0)$ & $0 \%$ \\
\hline First & 23 & $1(4.3)$ & $2(8.3)$ & $11(16.2)$ \\
\hline Second & 68 & $2(2.9)$ & $13(14.1)$ & $13.0 \%$ \\
\hline Total & 92 & $3(3.3)$ & $\begin{array}{c}\text { Lower: }-0.159 \\
\text { Upper: } 0.032\end{array}$ & $17.4 \%$ \\
\hline \multicolumn{2}{|c|}{ Statistical Test $(95 \% \mathrm{CI})$} & $\begin{array}{c}\text { Lower: }-0.043 \\
\text { Upper: } 0.030\end{array}$ \\
\hline
\end{tabular}

This table shows the point prevalence rates of rubella infection within the pregnancy trimester variable. Statistical testing with $95 \%$ CI shows significance.

\section{Data Entry and Analysis}

Prevalence was defined as old and new cases (i.e. IgG and $\operatorname{IgM}$ positives), existing in the population during the study period [16]. Data entry and analysis were carried out with the SPSS 11 and Microsoft Excel 2003 softwares. Data was statistically tested using the Chi-square and the T-test. Results were considered to be statistically significant where $p<0.05$.

\section{RESULTS}

Multigravid pregnant women made up the majority (50; $54.35 \%$ ) of the subjects, as well as second trimester pregnant women $(68 ; 73.9 \%)$. Although most $(48 ; 52 \%)$ of the subjects had live children, some reported past pregnancy losses $(13 ; 14.1 \%), 50 \%$ of which occurred around the $10^{\text {th }}$ week of gestation.
Rubella virus-specific IgG and IgM antibodies were detected in the sera of 3 subjects; IgG antibodies were detected in the sera of 11 subjects, while 1 subject had only IgM antibodies detected in her sera. Fig. (1) shows the Distribution of Rubella Virus-specific IgG and IgM in the sera of the subjects. The obtained prevalence rate of this study was $16.3 \%$. The age-stratified prevalence rates of $1.1 \%, 3.3 \%, 9.8 \% 3.3 \%, 1.1 \%$ and $0 \%$ were observed in the pregnant women within age groups 16-20, 21-25, 26-30, 31$35,36-40$ and $41-50$ respectively $(\mathrm{p}>0.05)$. However, pregnant women with primary education, secondary, tertiary and no education had prevalence rates of $2.2 \%, 6.5 \%, 7.6 \%$ and $2.2 \%$ respectively $(\mathrm{p}<0.05)$.

Tables $\mathbf{1}$ and $\mathbf{2}$ show the prevalence of Rubella Virus infection amongst Primigravid and Multigravid Pregnancies, and Pregnancy Trimesters respectively.

Table 3. Relationship between Rubella Virus-Specific IGG and IGM Antibodies and Pregnancy Loss (N $=92)$

\begin{tabular}{|c|c|c|c|c|c|c|c|c|}
\hline \multirow{2}{*}{$\begin{array}{c}\text { Pregnancy } \\
\text { Loss }\end{array}$} & \multicolumn{4}{|c|}{ IgG } & \multicolumn{3}{c|}{ IgM } \\
\cline { 2 - 10 } & Border Line (\%) & Negative (\%) & Positive (\%) & Total (\%) & Border Line (\%) & Negative (\%) & Positive (\%) & Total (\%) \\
\hline \hline N/A & $0(0)$ & $1(6.7)$ & $0(0)$ & $1(6.7)$ & $1(33.3)$ & $0(0)$ & $0(0)$ & $1(33.3)$ \\
\hline No & $7(46.7)$ & $0(0)$ & $4(26.7)$ & $11(73.3)$ & $1(33.3)$ & $0(0)$ & $1(33.3)$ & $2(66.7)$ \\
\hline Yes & $1(6.7)$ & $0(0)$ & $2(13.3)$ & $3(20)$ & $0(0)$ & $0(0)$ & $0(0)$ & $0(0)$ \\
\hline Total & $8(53.3)$ & $1(6.7)$ & $6(40)$ & $15(100)$ & $2(66.7)$ & $0(0)$ & $1(33.3)$ & $3(100)$ \\
\hline
\end{tabular}

IgG: $\mathrm{X}^{2}=15.95, \mathrm{df}=4, \mathrm{p}=0.003 / \operatorname{IgM}: \mathrm{X}^{2}=7.50, \mathrm{df}=4, \mathrm{p}=0.112$.

This table shows the relationship between rubella virus-specific IgG and IgM antibodies and pregnancy loss. It was observed that of the 15 women whose sera tested positive for rubella virus-specific IgG antibodies, $3(20 \%)$ had history of pregnancy loss $(\mathrm{p}<0.05)$. However, of the 3 pregnant women whose sera tested positive for rubella virus-specific IgM antibodies, none had history of pregnancy loss. 
Table 3 shows the relationship between rubella virusspecific $\operatorname{IgG}$ and $\operatorname{IgM}$ antibodies and pregnancy loss. It revealed that, of the 15 women whose sera tested positive for rubella virus-specific IgG antibodies, $3(20 \%)$ had previous history of pregnancy loss $(\mathrm{p}<0.05)$. However, of the 3 pregnant women whose sera tested positive for rubella virusspecific IgM antibodies, there was no case of pregnancy loss $(\mathrm{p}>0.05)$. Table 4 presents the clinical symptoms reported by the pregnant women, while Tables $\mathbf{4}$ and $\mathbf{5}$ show the relationship between rubella virus-specific IgG and IgM antibody and clinical symptoms reported by the pregnant women.

Multiple clinical symptoms of rubella virus infection were recorded in the pregnant women. However, of the 92 pregnant women, $1(1.1 \%)$ reported to have had all four clinical symptoms to rubella virus infection (i.e. swollen lymph nodes, joint pains, rashes and fever), 2 (2.3\%) reported a combination of fever, rashes and joint pains, while $5(5.7 \%)$ reported fever and joint pains only $(\mathrm{p}<0.05)$. It was also observed that $1(6.7 \%)$ of the pregnant women that had rubella virus-specific IgG antibodies presented with rash; although none of the women reported swollen lymph nodes, $3(20 \%)$ women however, reported joint pains, while 3 $(20 \%)$ others reported fever $(\mathrm{p}<0.05)$. It was also observed that $1(6.7 \%)$ of the pregnant women that had rubella virusspecific $\operatorname{IgM}$ antibodies had no clinical symptoms ( $p>0.05)$.

\section{DISCUSSION}

The predominance of first antenatal reporting in the second trimester of pregnancy confirms the claim that most pregnant women in Ilorin report late for antenatal care [Agbede, 2009, Personal Communication]. Thus, assessment of risk burdens for congenital anomalies may prove difficult in the study area. The reported cases of pregnancy loss (during organogenesis) by some of the pregnant women may be a reflection of the teratogenic effect of rubella infection or the effect of other teratogenic agents of the TORCH complex on first and second trimester pregnancies [2].

\section{Rubella Virus-Specific IgG Antibody}

The detection of Rubella virus-specific IgG in the sera of $14(15.22 \%)$ of the pregnant women that participated in this study $(\mathrm{p}<0.05)$ implies that such women were exposed to rubella virus and thereafter naturally developed lifelong immunity against the infection [11]. This is because none of the pregnant women had ever received antirubella vaccines. Borderline IgG results however, reflect ongoing development of rubella virus-specific IgG and IgM antibodies in the sera of the pregnant women.

\section{Rubella Virus-Specific IgM Antibody}

The detection of rubella virus-specific antibodies of the IgM class in the sera of $3(3.26 \%)$ of the 92 pregnant women that participated in confirmed that rubella infection was ongoing in those pregnant women [8]. Thus implies a possibility that the infection occurred at least 10 days earlier [1]. However, detection of IgM class of antibodies was reported as positive and borderline - which highlight the course of the ongoing infection. The two borderline IgM test results which were recorded in two subjects indicate the possibility of an ongoing infection that was captured after about four months and at least 10 days since the infection occurred respectively [1].

\section{Primary Rubella Virus Infection}

It was observed that one patient's sample sera had a Borderline IgM test result and a negative antirubella IgG test result. This implies the possibility of a recent rubella infection occurring about ten days prior to the serum test [1]. However, the participant was a 34-year old woman in her second trimester of pregnancy but did not respond to the questionnaire.

\section{THE RUBELLA PREVALENCE IN THE PREGNANT WOMEN}

The low prevalence rate of rubella virus infections observed from the results obtained $(16.3 \%)$ in this study as compared to previous studies carried out in south western Nigeria (58\%) and North Western Nigeria (63\%) may be attributed to the rainy season during which the study was carried out (June to September 2009). However, these studies mentioned did not specify the period in which they were carried out nor did they specify the duration of study. In addition, reported epidemics of rubella (in the temperate climates) have been observed to occur in seasonal patterns during the late winter with peaks in the springs $[1,11]$. A tropical correlate will be the dry (Harmatan) season - during which the very low humidity promotes the easy transmission of postnatal rubella infections (through the respiratory route).

\section{Prevalence of Rubella Virus Infection among Variables}

The age-stratified prevalence of rubella infection among the pregnant women below 20 years of age was $20 \%$, which has no statistical difference from the results obtained in other studies carried out among pregnant women aged 14 to 19 years $(23.8 \%)$ in Maiduguri (North-eastern Nigeria) [15]. However, this study showed an initial increase followed by a

Table 4. Clinical Symptoms Reported among Pregnant Women $(\mathrm{N}=92)$

\begin{tabular}{|c|c|c|c|c|}
\hline Clinical Symptoms & Total No. & No Response (\%) & Yes $(\%)$ & No $(\%)$ \\
\hline Rashes & 87 & $0(0)$ & $3(3.4)$ & $84(96.6)$ \\
\hline Swollen lymph nodes & 92 & $5(5.4)$ & $1(1.1)$ & $86(93.5)$ \\
\hline Fever & 92 & $5(5.4)$ & $16(17.4)$ & $71(77.2)$ \\
\hline
\end{tabular}

$\mathrm{X}^{2}=4.0, \mathrm{df}=1, \mathrm{p}=0.046$

This table presents the various clinical symptoms of rubella infection, reported by the pregnant women that participated in this study. Of the 92 pregnant women, 3 ( $3.4 \%)$ reported rashes, $13(14.1 \%)$ reported joint pains, $1(1.1 \%)$ reported swollen lymph nodes and $16(17.4 \%)$ reported fever. This result however shows statistical significance. 
Table 5. Relationship between Rubella Virus-Specific IGG AND IGM Antibodies and Clinical Symptoms (N =92)

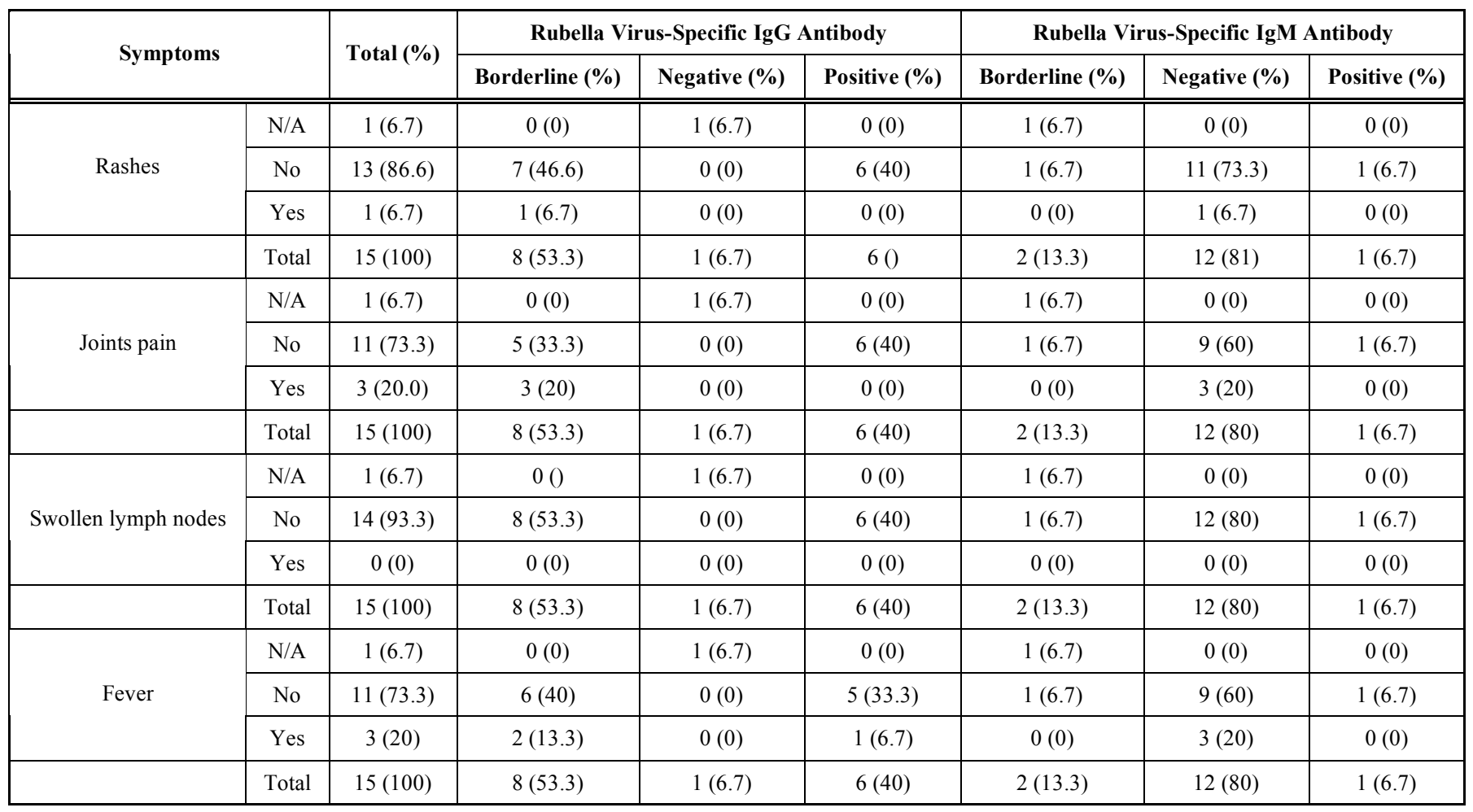

\begin{tabular}{|c|c|c|c|c|c|}
\hline \multicolumn{2}{|c|}{ Symptoms } & \multirow{2}{*}{$\begin{array}{c}\text { IgG } \\
15.000\end{array}$} & \multicolumn{2}{|c|}{ Symptoms } & \multirow{2}{*}{$\frac{\text { IgM }}{26.964}$} \\
\hline \multirow{2}{*}{ Swollen lymph nodes } & Chi-square & & \multirow{2}{*}{ Swollen lymph nodes } & Chi-square & \\
\hline & Sig. & 0.001 & & Sig. & 0.031 \\
\hline \multirow[t]{2}{*}{ Fever } & Chi-square & 15.152 & Fever & Chi-square & 7.500 \\
\hline & Sig. & 0.004 & & Sig. & 0.112 \\
\hline \multirow[t]{3}{*}{ Rashes } & Chi-square & 15.865 & Rashes & Chi-square & 7.115 \\
\hline & df & 4 & & df & 4 \\
\hline & Sig. & 0.003 & & Sig. & 0.130 \\
\hline
\end{tabular}

This table shows the Relationship between rubella virus-specific IgG and IgM antibody and clinical symptoms in the pregnant women. It was observed that 1 (6.7\%) of the pregnant women that had rubella virus-specific IgG antibodies reported rashes $(\mathrm{p}<0.05), 3(20 \%)$ reported joint pains $(\mathrm{p}<0.05)$, none reported swollen lymph nodes ( $<<0.05)$, while $3(20 \%)$ reported fever $(\mathrm{p}<0.05)$. Also, $1(6.7 \%)$ of the pregnant women that had rubella virus-specific IgM antibodies reported no clinical symptoms ( $>0.05)$.

decrease in the prevalence among the increasing age groups ( $>0.05)$, with the highest prevalence occurring amongst the pregnant women aged $26-30$ years $(9.8 \%)$.

This study also shows that religion, education and Marital Status are not to be neglected by health planners in preparing immunization strategies. Since married pregnant women were observed to be better educated than the single pregnant women, and women with tertiary education were also observed to be more exposed to rubella infections than any other level of education, this therefore implies that such infections could have been acquired outside the homes of the affected pregnant women and possibly in a closely packed environment which describes the average classroom or lecture room in Ilorin. However, further research in higher institutions would be required to confirm this claim.

\section{Prevalence of Rubella Virus Infection amongst Pregnancy Gravidity and Trimesters}

Although most of the pregnant women were multigravid, the result of this study showed a higher prevalence in the primigravid women $(27 \%)$ than the multigravid women $(12 \%)$. This result however shows that multigravidity may 
not be a predisposing factor to rubella virus infection or immunity. However, results showed a gradual rise in seroprevalence from $13.04 \%$ amongst first trimester pregnancies to $19.12 \%$ in second trimester pregnancies. This increase was also reported in the study carried out in Maidugury [15]. The statistical significant tests however reveal the gravity of foetal risk to congenital rubella infection in Ilorin and possibly provide an explanation for a recent case of congenital anomalies observed in a new born delivered at the University of Ilorin Teaching Hospital, Ilorin, Nigeria [Ekundayo, 2011, Personal Communication].

\section{Prevalence of Rubella Virus Infection among Pregnant Women who had Lost Pregnancies}

The 3 women whose medical history revealed pregnancy losses during organogenesis and also tested positive for rubella virus-specific $\operatorname{IgG}$ antibodies $(\mathrm{p}<0.05)$, suggests that previous exposures to teratogenic agents during organogenesis was debilitating to the foetal development. The tell-tale sign of rubella virus in the sera of these women implicates the virus as possible cause of the abortions; however, further tests would be required to confirm these assertions.

\section{CORRELATION OF CLINICAL SYMPTOMS WITH RUBELLA VIRUS INFECTION OF PREGNANT WOMEN}

The clinical symptoms reported by pregnant women are descriptive of rubella virus infection, although not all observed cases had all symptoms and some cases had no symptoms at all $[6,15]$. The observed rubella virus-specific $\operatorname{IgG}$ antibodies amongst clinical symptoms of fever $(20 \%)$, joint pains $(20 \%)$ and rashes $(6.7 \%)(p<0.05)$, is in accordance with the claim that rubella virus infections may be subclinical in certain subjects for reasons yet unknown $[4,6]$.

It has been established that acute rubella virus infections that occur in early pregnancy may induce foetal death or congenital rubella syndrome [3]. However, this study has reported a seroprevalence of $13.04 \%$ in the first trimester of pregnancy and $19.12 \%$ in the second trimester of pregnant women in Ilorin. This indicates a high risk to foetus. In addition, a higher prevalence was recorded in primigravidae than in multigravidae, with the highest age-stratified prevalence occurring in women aged $31-35$ years. In addition, since $85 \%$ of pregnant women in Ilorin are susceptible to rubella virus infection, it is advisable for health planners to prevent further cases of antenatal rubella which may result to congenital rubella anomalies which may result to a debilitating impact on the National Gross Domestic Product due to health impairments.

Therefore, these results could serve as guide to health planners for possible interventions in preventing congenital rubella syndromes by mass vaccination of women of child bearing age [11] with special focus on teenagers and early adults.

\section{ABBREVIATIONS}

CRS $=$ Congenital Rubella Syndrome

EPI $=$ Expanded Program of Immunization
IgA $=$ Alpha $(\alpha)$ Immunoglobulin

$\operatorname{IgM}=\mathrm{Mu}(\mu)$ Immunoglobulin

KAP $=$ Knowledge, Attitude and Practice

MMR = Measles, Mumps and Rubella

RNA $=$ Ribonucleic Acid

SPSS = Statistical Publishing Society Software

TORCH = Toxoplasmosis, Rubella, Cytomegalovirus, Herpes and Others (which include type B hepatitis virus, coxasckie virus, mumps virus, polio virus, rubeola, Varicella zoster virus, Listeria, Gonorrhoea, Streptococcus and Treponema)

UITH = University of Ilorin Teaching Hospital, Ilorin, Nigeria

WHO $=$ World Health Organisation

\section{ACKNOWLEDGEMENTS}

Research Assistance:

- ELKANAH Folashade Abosede Department of Microbiology, University of Ilorin.

- ETUKAKPAN Ntukidem Mayen Department of Medical Microbiology and Parasitology, University of Ilorin.

\section{REFERENCES}

[1] Hobman T, Chantler J. Rubella Virus. In: Knipe DM, Howley PM, Griffin DE, Martin MA, Lamb RA, Roizman B, Straus SE, Eds. Fields Virology, $5^{\text {th }}$ ed. PA, USA: Lippincott Williams \& Wilkins 2007; 1069-1100.

[2] Porth CM. Pathophysiology concepts of altered health states, $4^{\text {th }}$ ed. Philadelphia, USA: J.B. Lippincott company 1994; 65-9.

[3] Shigetaka K. Rubella virus gene diagnosis during pregnancy and mechanism of congenital rubella. Intervirology 1998; 41: 163-9.

[4] Manuals for the laboratory diagnosis of measles and rubella virus infection. $2^{\text {nd }}$ ed. Geneva, Switzerland: WHO. 2007.

[5] Banatvala JE, Brown DWG. Rubella. Lancet 2004; 363: 1127-37.

[6] Dontigny L, Arsenault M, Martel M. Rubella in pregnancy. J Obstet Gynaecol Can 2008; 30(2): 152-8.

[7] Niwa Y, Kanoh TK. Immunological behaviour following rubella infection. Clin Exp Immunol 1979; 37: 470-6.

[8] Robertson SE, Featherstone DA, Gacic-Dobo M. Rubella and congenital rubella syndrome: global update. Pan Am J Pub Health 2003; 14(5): 306-15.

[9] WHO-recommended standards for surveillance of selected vaccine-preventable diseases. Geneva, Switzerland: WHO. 2003.

[10] WHO position paper. Rubella vaccines. Wkly Epidemiol Rec 2000; 75(20): pp. 161-72.

[11] Cutts FT, Robertson SE, Diaz-Ortega J-L, Samuel R. Control of rubella and congenital rubella syndrome (CRS) in developing countries, part 1: burden of disease from CRS. Bull WHO 1997; 75(1): 55-68

[12] Babalola OE, Babalola BI. Congenital eye diseases in Abuja, Nigeria. Niger J Ophthal 2004; 12(2): 46-9.

[13] Bamgboye AE, Afolabi KA, Esumeh FI, Enweani IB. Prevalence of rubella antibody in pregnant women in Ibadan, Nigeria. West Afr J Med 2004; 23: 245-8.

[14] Onyenekwe CC, Kehinde-Agbeyangi TA, Ofor US, Arinola OG. Prevalence of rubella-IgG antibody in women of childbearing age in Lagos, Nigeria. West Afr J Med 2000; 19(1): 23-6.

[15] Bukbuk DN, EL-Nafaty AU, Obed JY. Prevalence of rubellaspecific IgG antibody in non-immunized pregnant women in 
Maiduguri, North Eastern Nigeria. Cent Eur J Public Health 2002; 10(1-2): 21-3.
[16] Park K. Principles of Epidemiology and Epidemiologic Methods. In: Park's Textbook of Preventive and Social Medicine, $19^{\text {th }}$ ed. Jabalpur, India: M/s Banarsidas Bhanot 2007; 49-114.

Received: July 23, 2010

Revised: March 09, 2011

Accepted: June 01, 2011

(C) Agbede et al.; Licensee Bentham Open.

This is an open access article licensed under the terms of the Creative Commons Attribution Non-Commercial License (http://creativecommons.org/licenses/by$\mathrm{nc} / 3.0 /$ ), which permits unrestricted, non-commercial use, distribution and reproduction in any medium, provided the work is properly cited. 